\title{
Analysis of Biological Parameters of Boophilus microplus Canestrini, 1887 Exposed to Entomopathogenic Nematodes Steinernema carpocapsae Santa Rosa and All Strains (Steinernema: Rhabditida)
}

\author{
Gláucia Marques Freitas-Ribeiro $^{1 *}$, John Furlong ${ }^{2}$, Viviane Oliveira Vasconcelos ${ }^{1}$, Cláudia \\ Dolinski $^{3}$ and Alan Loures-Ribeiro ${ }^{4}$ \\ ${ }^{1}$ Universidade Federal de Juiz de Fora; Pós-Graduação em Comportamento e Ecologia Animal; Campus \\ Universitário; Martelos; 36033-330; Juiz de Fora - MG - Brasil. ${ }^{2}$ Embrapa Gado de Leite; Rua Eugênio do \\ Nascimento,610; Bairro Dom Bosco; 36038-330; Juiz de Fora - MG - Brasil. ${ }^{3}$ Universidade Estadual do Norte \\ Fluminense; Av. Alberto Lamego, 2000; Pq. Califórnia; 28013-620; Campos dos Goytacazes - RJ - Brasil. \\ ${ }^{4}$ Universidade Federal de São Carlos; Programa de Pós-Graduação em Ecologia e Recursos Naturais; Via \\ Washington Luiz, Km 235; C. P. 676; 13565-905; São Carlos - SP - Brasil
}

\begin{abstract}
Engorged and partially engorged females of Boophilus microplus were exposed to 600; 3,000; 6,000 and 30,000 infective juveniles of Steinernema carpocapsae Weiser, 1955 Santa Rosa and All strains per dish, under lab conditions. Eggs weight, pre-laying period, laying period, survival period, reproductive efficiency rate, percentage of larval eclosion and lethal concentrations of $50 \%$ and $90 \%\left(C \xi_{0}\right.$ and $\left.C L_{90}\right)$ were calculated for engorged females. In the case of partially engorged females, only egg weight, survival period and $C L_{50}$ and $C L_{90}$ were calculated. All biological parameters of engorged or partially engorged females were altered by exposition of $S$. carpocapsae infective juveniles (IJS), Santa Rosa and All strains ( $p<0.05)$. The increase in the response was directly proportional to the increase of IJs concentration per Petri dish $(p<0.05)$. Results suggested that entomopathogenic nematodes could have a positive role in the control of cattle tick.
\end{abstract}

Key words: Boophilus microplus, Steinernema carpocapsae, entomopathogenic nematodes, cattle tick, reproduction

\section{INTRODUCTION}

Boophilus microplus is a very important cattle parasite (Veríssimo, 1993). Due to widespread resistance commercial parasite-killers and environmental conservation, many alternatives to chemical control have been highlighted (Samish, 2000), especially the use of entomopathogenic nematodes as potential biological control (Gaugler, 2002). Easy handling, long storage time, resistance to environmental variables, nonmandatory register and compatibility with chemical products are some of its many beneficial aspects (Wouts, 1991). However, the most important characteristic of entomopathogenic nematodes while controlling $B$. microplus is their capability to support the spray pressure used with traditional chemical control, being capable to be applied with different nozzles types and models as

\footnotetext{
* Author for correspondence
} 
much as conventional tick killers (Shetlar, 1999; Piggott et al., 2003; Fife et al., 2004).

Little is known on the control of cattle ticks with entomopathogenic nematodes, as biological control agent (Máuleon et al., 1993). Therefore, the aim of this work was to investigate the changes of certain biological parameters in engorged and partially engorged females of Boophilus microplus exposed to different concentrations of Steinernema carpocapsae Santa Rosa and All strains (Zhioua et al., 1995).

\section{MATERIALS AND METHODS}

Experiment was undertaken at Embrapa Gado de Leite, Juiz de Fora, MG, Brazil, between March and July 2002. Inoculums of infective juveniles of S. carpocapsae, Santa Rosa strain, were donated by the Vegetal Biotechnological Department (UFSCar), Araras SP, Brazil, S. carpocapsae All strain was donated by the Plant Protection Lab (UENF), Campos dos Goytacazes, RJ, Brazil. Entomopathogenic nematodes were isolated from Araras, SP.

\section{Nematode Multiplication}

Seventh instar of Galleria mellonella larvae (Lepidoptera: Pyralidae), weighing about $0.26 \mathrm{~g}$, were used for the in vivo nematode production (Lindegren et al. 1993). Two milliliters of aqueous suspension were used; $0.004 \mathrm{ml}$ of infective juveniles of nematodes was added and placed on 9 cm-diameter Petri dishes with two filter papers. Ten larvae were placed on the dishes; the material was wrapped in a plastic film and kept in a germination chamber for $48 \mathrm{~h}$ at $28{ }^{\circ} \mathrm{C}$. Infected dead larvae were then transferred to White's traps (Kaya and Stock, 1997) for collecting nematodes. After eight to ten days, infective juveniles that migrated to the water in trap were collected.

\section{Ticks}

Females of Boophilus microplus (sensitive Porto Alegre stock) came from Embrapa Gado de Leite stock. Engorged females were collected after natural detachment from cattle, whereas partially engorged females were removed by hand.

\section{Exposure of ticks}

Engorged and partially engorged female of $B$. microplus were exposed to infective juveniles of $S$. carpocapsae Santa Rosa and All strains.
Concentrations tested were $600 ; 3,000 ; 6,000$ and 30,000 of infective juveniles (IJs) per Petri dish. Two millimeters of IJs were evenly spread on $5 \mathrm{~cm}$-diameter Petri dishes with $15 \mathrm{~g}$ of sterile sand as substrate. Control consisted of $2 \mathrm{ml}$ of nematode-free distilled water. Six engorged and partially engorged females were used for each dish. Five and three dishes were tested respectively for engorged $(n=30)$ and partially engorged $(n=18)$ females.

Ticks were exposed to nematodes during $72 \mathrm{~h}$ and then transferred to clean dishes (without sand or nematodes). During exposition and post-exposition time, the dishes were maintained in germination chambers at $27 \pm 1^{\circ} \mathrm{C}$, and relative humidity above $80 \%$. Tick mortality was registered daily through observations of leg reflexes and by color and smell changes.

\section{Biological Parameters}

Following data were taken from engorged females: egg weight at the end of laying period or up to the female's death; pre-laying period, from the date of the treatment until they started laying eggs; laying period, the period between the beginning and end of laying; survival time, from exposition until female's death; index of reproductive efficiency (egg masses weight divided by the females' initial weight multiplied by 100) (Bennett, 1974); larval hatching percentage. Egg masses weight and survival period were taken from partially engorged females. The concentration of infected juveniles of S. carpocapsae Santa Rosa and All strains, enough to achieve 50 and $90 \%$ of engorged and partially engorged females mortality $\left(\mathrm{CL}_{50}\right.$ and $\left.\mathrm{CL}_{90}\right)$ was also calculated.

\section{Statistical Analysis}

Rates of biological parameters of B. microplus were compared by Kruskal-Wallis test $(\mathrm{p}<0.05)$. Dunn test was employed to pinpoint the groups that differed among themselves. Transformation of all percentage data was made by arcsine square root. $\mathrm{CL}_{50}$ and $\mathrm{CL}_{90}$ of $B$. microplus were calculated by Probit analysis (SAS Institute, 1989).

\section{RESULTS AND DISCUSSION}

All biological parameters for engorged and partially engorged $B$. microplus females were affected by IJs exposition (Tables 1, 2, 3). 
Engorged females exposed to $S$. carpocapsae Santa Rosa strain

Significant differences $(\mathrm{p}<0.05)$ were noted between control and treated groups in pre-laying and laying periods, even though there was no difference among the treated groups ( $p>0.05)$. Egg weight, reproductive efficiency index (REI) and survival period decreased significantly in treated groups $(\mathrm{p}<0.05) \quad($ Table 1$)$. Concentrations of
3,000; 6,000 and 30,000 IJs/dish did not differ for the latter parameters. Hatching rate decreased significantly when comparing control and treatments $(\mathrm{p}<0.05)$.

Cumulative females mortality were proportional to the increase of IJs concentration (Fig. 1). After the fifth day of exposure $\mathrm{CL}_{50}$ and $\mathrm{CL}_{90}$ were calculated as 3,596 and 169,441 infective juveniles per dish.

Table 1 - Average values of biological parameters of Boophilus microplus engorged females artificially exposed to Steinernema carpocapsae Santa Rosa infective juveniles.

\begin{tabular}{|c|c|c|c|c|c|}
\hline Parameters & \multicolumn{5}{|c|}{ Concentration of infective juvenile $/ q$ Boophilus microplus } \\
\hline & Control & 600 & 3000 & 6000 & 30000 \\
\hline o Initial weight ${ }^{1}$ & $0,270 \pm 0,026^{\mathbf{a}}$ & $0,261 \pm 0,045^{\mathrm{a}}$ & $0,267 \pm 0,047^{\mathbf{a}}$ & $0,261 \pm 0,043^{\mathbf{a}}$ & $0,257 \pm 0,034^{\mathrm{a}}$ \\
\hline $\mathrm{P}_{\mathrm{mo}}{ }^{1}$ & $0,138 \pm 0,032^{\mathrm{a}}$ & $0,042 \pm 0,034^{\mathbf{b}}$ & $0,034 \pm 0,039^{\mathbf{b}, \mathbf{c}}$ & $0,006 \pm 0,012^{\mathbf{c}}$ & $0,010 \pm 0,020^{\mathbf{c}}$ \\
\hline $\mathrm{PP}_{\mathrm{p}}^{2}$ & $3,03^{\mathbf{a}}$ & $4,58^{b}$ & $4,18^{\mathbf{b}}$ & $4,75^{b}$ & $5,4^{\mathrm{b}}$ \\
\hline$q \mathrm{P}_{\mathrm{p}}^{2}$ & $12,36^{\mathbf{a}}$ & $7,37^{\mathbf{b}}$ & $8,00^{\mathbf{b}}$ & $3,0^{\mathrm{c}}$ & $3,1^{\mathrm{c}}$ \\
\hline$+\mathrm{T}_{\mathrm{SO}}^{2}$ & $23,36^{\mathbf{a}}$ & $11,5^{\mathrm{b}}$ & $10,3^{\mathbf{b , c}}$ & $7,9^{\mathrm{c}}$ & $7,2^{\mathrm{c}}$ \\
\hline q R.E.I. & $46,18 \pm 3,92^{\mathrm{a}}$ & $20,66 \pm 13,14^{\mathbf{b}}$ & $14,83 \pm 16,20^{\mathbf{b , c}}$ & $5,18 \pm 7,83^{\mathrm{c}}$ & $6,03 \pm 9,80^{\mathrm{c}}$ \\
\hline $\mathrm{T}_{\mathrm{E}}(\%)$ & $73,66^{\mathrm{a}}$ & $34,56^{\mathbf{b}}$ & $20,31^{\mathbf{b}}$ & $1,66^{\mathbf{b}}$ & $1,00^{\mathbf{b}}$ \\
\hline
\end{tabular}

Table 2 - Average values of biological parameters of Boophilus microplus engorged females artificially exposed to Steinernema carpocapsae All infective juveniles.

\begin{tabular}{|c|c|c|c|c|c|}
\hline Parameters & \multicolumn{5}{|c|}{ Concentration of infective juvenile $/ \subseteq$ Boophilus microplus } \\
\hline & Control & 600 & 3000 & 6000 & 30000 \\
\hline O Initial weight ${ }^{1}$ & $0,270 \pm 0,026^{\mathbf{a}}$ & $0,267 \pm 0,041^{\mathbf{a}}$ & $0,269 \pm 0,032^{\mathrm{a}}$ & $0,257 \pm 0,027^{\mathrm{a}}$ & $0,260 \pm 0,036^{\mathrm{a}}$ \\
\hline $\mathrm{P}_{\mathrm{mo}}^{1}$ & $0,138 \pm 0,032^{\mathbf{a}}$ & $0,029 \pm 0,034^{\mathbf{b}}$ & $0,002 \pm 0,010^{\mathbf{c}}$ & $0^{\mathbf{c}}$ & $0,001 \pm 0,005^{\mathbf{c}}$ \\
\hline$+\mathrm{PP}_{\mathrm{p}}^{2}$ & $3,03^{\mathrm{a}}$ & 3,37 & 5,0 & 4,0 & 4,0 \\
\hline$q \mathrm{P}_{\mathrm{p}}^{2}$ & $12,36^{\mathrm{a}}$ & 4,27 & 2,14 & 1,0 & 2,5 \\
\hline q $\mathrm{T}_{\mathrm{SO}}^{2}$ & $23,36^{\mathrm{a}}$ & $7,7^{\mathbf{b}}$ & $4,43^{\mathrm{c}}$ & $3,8^{\mathbf{c}}$ & $3,63^{\mathrm{c}}$ \\
\hline क R.E.I. & $46,18 \pm 3,92^{\mathrm{a}}$ & $16,62 \pm 12,19^{\mathbf{b}}$ & $2,28 \pm 6,0^{\mathrm{c}}$ & $0,23 \pm 0,88^{\mathbf{c}}$ & $0,97 \pm 4,02^{\mathrm{c}}$ \\
\hline $\mathrm{T}_{\mathrm{E}}(\%)$ & $73,66^{\mathrm{a}}$ & 11,37 & 7,14 & 0 & 16,66 \\
\hline
\end{tabular}


Engorged females exposed to $S$. carpocapsae All strain

Six biological parameters were assessed (Table 2). Egg weight, survival period and REI were significantly different between the control and treated groups $(p<0.05)$. Among the different concentration treatments, only 600 IJs/dish showed significant difference $(p<0.05)$. Cumulative mortality rates are proportional to high IJs concentrations (Fig. 2). $\mathrm{CL}_{50}$ and $\mathrm{CL}_{90}$ were respectively 171 and $451 \mathrm{IJ} /$ dish after the fifth day exposed to $S$. carpocapsae All.

Partially engorged females exposed to $S$. carpocapsae Santa Rosa strain

Only the egg weight and survival period were analyzed in the case of partially engorged females
(Table 3). Females from groups with 6,000 and 30,000 infective juveniles/dish failed to lay eggs. There were significant differences between the treatments and the control when egg masses weight was taken into account $(p<0.05)$. Females' survival period only showed significant differences in the control group and in 3,000; 6,000 and 30,000 IJs treatment groups. When the treatment groups are considered, the two highest IJs concentrations differed from the two lowest ones $(p<0.05)$. Figure 3 shows in details cumulative mortality of partially engorged females. After the third day of exposition to $S$. carpocapsae Santa Rosa strain, the lethal nematode concentration that killed 50\% and $90 \%$ of partially engorged females comprised 561 and 2,392 infective juveniles, respectively.

Table 3 - Average values of biological parameters of Boophilus microplus partially engorged females exposed to Steinernema. carpocapsae Santa Rosa and All strains.

\begin{tabular}{|c|c|c|c|c|}
\hline \multirow[b]{2}{*}{$\begin{array}{l}\text { Nematodes } \\
\text { strains }\end{array}$} & \multicolumn{4}{|c|}{ Parameters } \\
\hline & $\begin{array}{c}\text { Infective juvenile } \\
\text { concentration / partially } \\
\text { ingurgitaded } q\end{array}$ & $\begin{array}{c}\text { Parcially engorged } q \\
\text { initial weight }^{1}\end{array}$ & $\mathbf{P}_{\mathrm{mo}}{ }^{1}$ & $q \mathbf{T}_{\mathbf{S O}}{ }^{2}$ \\
\hline & Control & $0,206^{\mathbf{a}}$ & $0,034^{\mathbf{a}}$ & $10^{\mathrm{a}}$ \\
\hline Santa Rosa & 600 & $0,209^{\mathbf{a}}$ & $0,017^{\mathbf{b}}$ & $7,38^{\mathbf{a}, \mathbf{b}}$ \\
\hline Santa Rosa & 3,000 & $0,200^{\mathrm{a}}$ & $0,006^{\mathbf{b , c}}$ & $4,47^{\mathbf{b}}$ \\
\hline Santa Rosa & 6,000 & $0,204^{\mathrm{a}}$ & $0^{\mathbf{c}}$ & $3,33^{\mathrm{c}}$ \\
\hline Santa Rosa & 30,000 & $0,198^{\mathrm{a}}$ & $0^{\mathbf{c}}$ & $3^{c}$ \\
\hline All & 600 & $0,206^{\mathrm{a}}$ & $0,007^{\mathbf{b}}$ & $6^{b}$ \\
\hline All & 3,000 & $0,208^{a}$ & $0,004^{\mathbf{b , c}}$ & $4,44^{\mathbf{b}}$ \\
\hline All & 6,000 & $0,207^{\mathrm{a}}$ & $0,002^{\mathbf{b , c}}$ & $4,27^{\mathbf{b}}$ \\
\hline All & 30,000 & $0,209^{\mathbf{a}}$ & $0^{\mathrm{c}}$ & $3,16^{b}$ \\
\hline
\end{tabular}

${ }^{1}$ - Gram; ${ }^{2}$ - Days. Egg masses weight $\left(\mathrm{P}_{\mathrm{mo}}{ }^{1}\right)$, survival period $\left(\mathrm{T}_{\mathrm{so}}{ }^{2}\right)$. Different letters (in bold) represent significant difference $(\mathrm{p}<0.05)$.

Partially engorged females exposed to $S$. carpocapsae All strain

Significant difference in egg weight has been evidenced in the control and treated groups $(p<0.05)$. Among the treated groups only 600 IJs/dish concentration was significant different from the others $(\mathrm{p}<0.05)$.

Survival period in the treatment groups were shorter than the control group $(\mathrm{p}<0.05)$, although no significant difference was found among treatments ( $>0.05)$ (Fig. 4). Lethal concentration of nematodes that killed $50 \%$ and $90 \%\left(\mathrm{CL}_{50}\right.$ and $\mathrm{CL}_{90}$ ) of partially engorged females, up to the third day of exposition, comprised 156 and 5,001 infected juveniles respectively.

In all treatments, pre-laying period was longer in the groups exposed to $S$. carpocapsae Santa Rosa strain, than in the control. This result differed from that found by Samish and Glazer (1992). In the latter $B$. annulatus females that survived 
exposition to $S$. carpocapsae Strain DT, started laying eggs at the same time as the females from the control group. Perhaps, the survival females from the experiments mentioned above haven't been infected by nematodes. As a consequence the pre-laying period and the egg masses weight were not affected when compared to the control treatment.

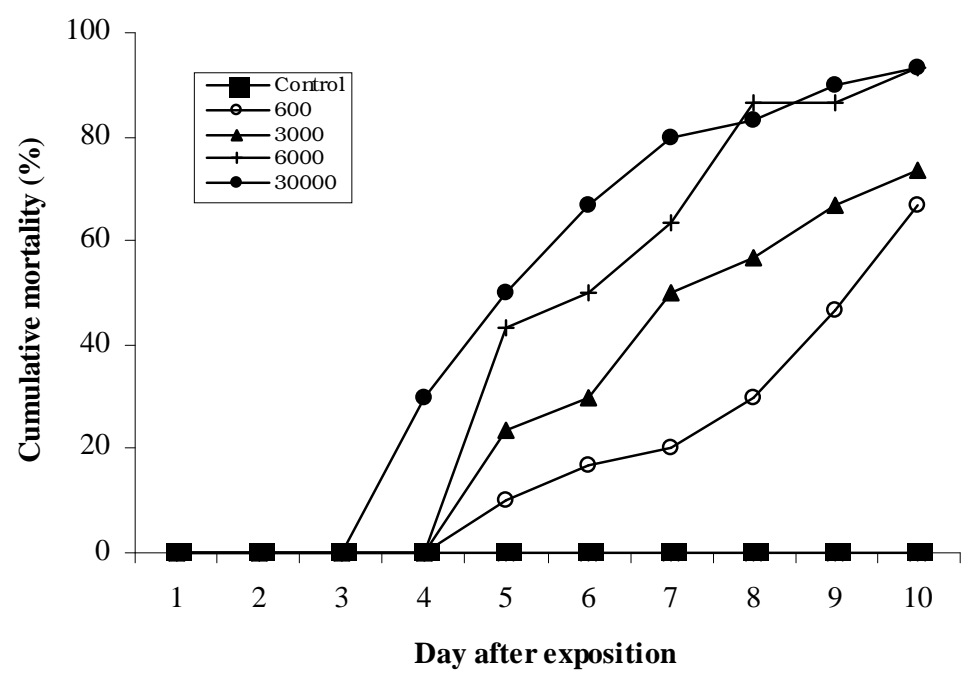

Figure 1 - Cumulative mortality of Boophilus microplus engorged females exposed to different concentrations of infective juveniles of Steinernema carpocapsae Santa Rosa strain.

Egg weight of $B$. microplus infected by $S$. carpocapsae Santa Rosa and All strains, differed from egg masses weight of the control group. Zhioua et al. (1995) also found that egg weight of Ixodis scapularis engorged females exposed to $S$. carpocapsae All strain was different from the control group, although no difference was detected among groups with different nematode concentrations. In our work differences were detected in the egg masses weights among infected groups exposed to different concentrations in the two $S$. carpocapsae strains. When the range of concentrations is small, a similar pathogenicity and egg masses weight may occur among treated groups. Besides that $I$. scapularis anatomy is different from B. microplus which could influence the nematode invasion. Infective juveniles of $S$. carpocapsae invades the host through natural openings such as spiracles, anus, mouth and genital pore (Wouts, 1991). When engorged females of Amblyomma maculatum were exposed to $S$. riobravis SR strain and to $S$. feltiae SF strain laying females had reduced egg masses (Kocan et al., 1998).

Contrastingly, Máuleon et al. (1993) showed that all $B$. microplus survived when exposed to a suspension of 1000 IJs of S. carpocapsae from nine different strains, All included. In these authors' opinion $B$. microplus must release some nematode-killer in the hemocel that repel or inhibit nematode reproduction. The lack of pathogenicity cause by $S$. carpocapsae All strain can be due to the methodology used for collecting infective juveniles. In lab experiments, the acquisition time is directly related to their infectivity. Downes (1996) showed that infective juveniles that emerge first, produce higher infectivity, since they can search, find and enter hosts easier than those juveniles that emerge latter.

Our results showed that increasing the number of infective juveniles/dish S. carpocapsae Santa Rosa and All strains produced a higher percentage of dead females (Figs. 1 and 2). Samish et al. (1999a) also found a mortality increase in Rhipicephalus sanguineus, Hyalomma excavatum and Rhipicephalus bursa when an increase in nematode concentrations occurred. On the other hand, the same positive correlation failed to occur in research by Zhioua et al. (1995), Kaaya et al. (2000) and Samish et al. (1999b). 


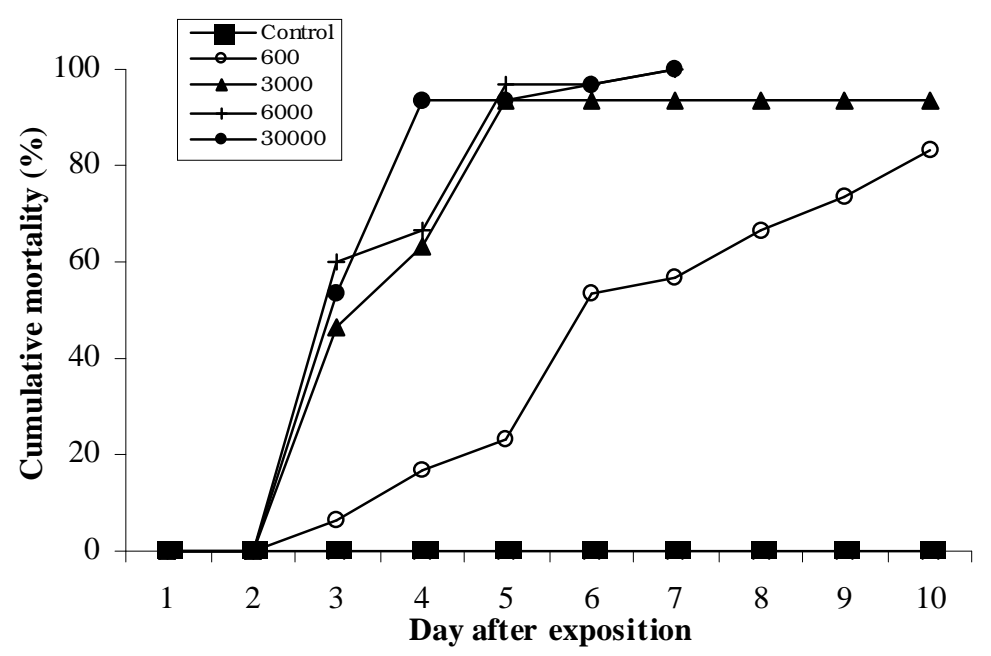

Figure 2 - Cumulative mortality of Boophilus microplus engorged females exposed to different concentrations of infective juveniles of Steinernem carpocapsae All strain.

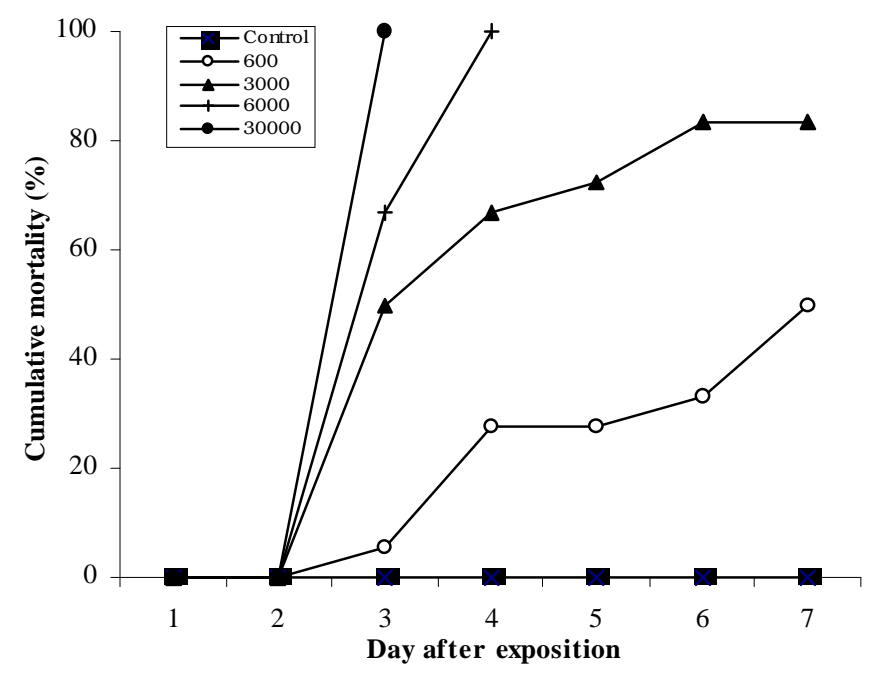

Figure 3 - Cumulative mortality of Boophilus microplus partially engorged females exposed to different concentrations of infective juveniles of Steinernema carpocapsae Santa Rosa strain.

Means of reproductive efficiency index (REI) of control group reached $46.18 \%$, close to $47.8 \%$ by Santos and Furlong (2002).

Only 26 out of 62 B. microplus females, exposed to $S$. carpocapsae Santa Rosa strain, produced larvae. Regarding females exposed to $S$. carpocapsae All strain, only 11, out of laying 40, produced larvae. When Hill (1998) exposed $I$. scapularis to $S$. carpocapsae All strain, and to $S$. feltiae Grub Guard strain, he found a mere egg mass of a hatching female out of four. Curiously, 6,000 IJs of $S$. carpocapsae All totally knock out larval hatching, while the concentration of 30,000 IJs aloud small hatching percentage. A similar fact was observed by Lewis et al. (1996), where the highest concentration was not capable to recognize the host. The interaction parasite-host may have suffered interference from the intra-specific competition. 


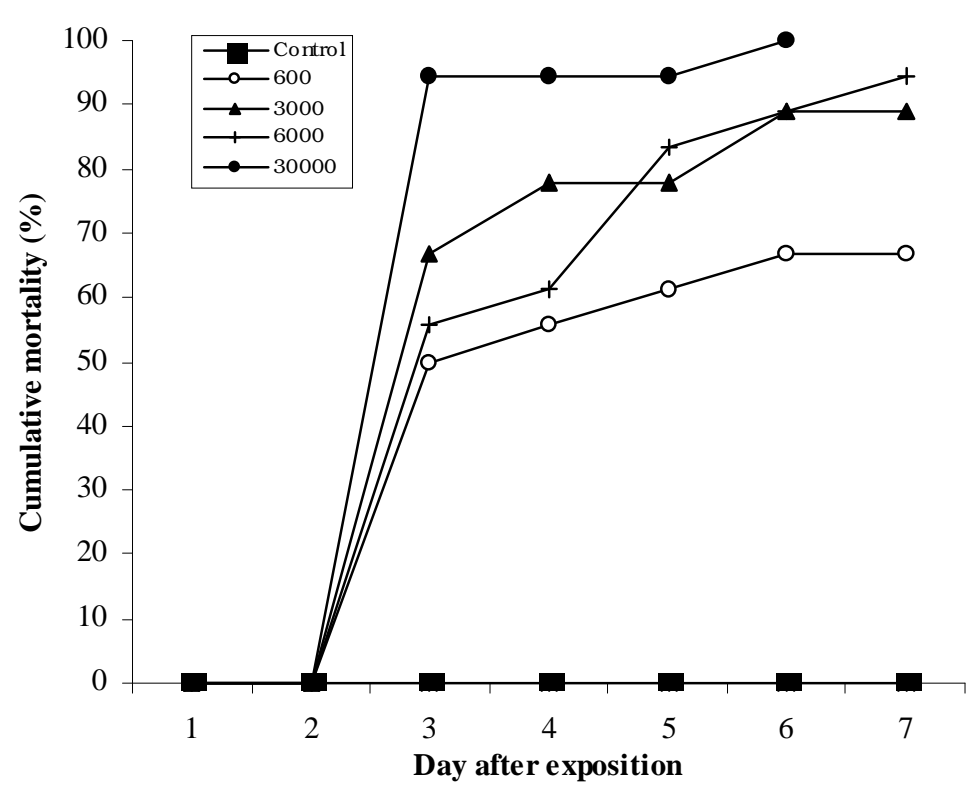

Figure 4 - Cumulative mortality of Boophilus microplus partially engorged females exposed to different concentrations of infective juveniles of Steinernema carpocapsae All strain.

When compared to earlier research, the different results could be accounted by various factors. This may be due to the period and region in which the nematode strains were isolated (Máuleon, et al., 1993). Infected juveniles dose used in tests, the time of exposure, temperature, relative humidity (environment chamber), and the symbiotic bacteria stock might have also affected results.

With regard to lethal concentrations that killed $50 \%$ of engorged females, contrasting differences among the two $S$. carpocapsae strains were noted. $S$. carpocapsae All strain infected juveniles were more pathogenic with a lower $\mathrm{CL}_{50}$ rate to engorged females. Similar results were found by Samish and Glazer (1992) and by Hill (1998) in their work on different $S$. carpocapsae strains. Actually All strain was more lethal to Ixodides.

Total mortality rate in partially engorged females of B. microplus occurred on the third day after exposure to 30,000 S. carpocapsae Santa Rosa strain, infective juveniles; similarly, total mortality rate was reached on the sixth day when partially infected females were exposed to $30,000 \mathrm{~S}$. carpocapsae All strain, infected juveniles. However, total mortality rate in $B$. microplus engorged females only occurred on the thirteenth day when exposed to the same nematode strains.
When Samish et al. (2000) employed engorged and non-engorged $B$. annulatus females and exposed them to $S$. carpocapsae DT and Mexican strains and to H. bacteriophora HP88, IS-5, IS-3 strains, the engorged females differed statistically from the non-engorged ones, dying slower than the others. Delay in death of engorged females was due to the mixture of the vertebrate host's blood to hemolymph of these filled females. This fact would cause an inadequate environment for multiplication of nematodes.

There is not much work in Brazil with ticks as entomopathogenic nematode hosts (Rhabdtida: Steinernematidae and Heterorhabditidae). Few studies with these nematodes have focused on control of sugarcane, citrus, banana, guava, ant and underground acarid pests (Grewal et al., 2001). This study showed that control of cattle ticks with entomopathogenic nematodes could be promising, since this method was free from chemical products and the damage to the environment could be highly reduced.

\section{ACKNOWLEDGEMENTS}

We would like to thank Marineide M. Aguillera and Regina C. Devitte (Federal University of São 
Carlos) for donation of nematodes. We are also grateful to Klinger Aparecido de Souza, Éder dos Santos (Embrapa Gado de Leite) and Romário C. Leite (Federal University of Minas Gerais) for their help and suggestions in our research. We also want to thank to CAPES and EMBRAPA Gado de Leite for the financial support.

\section{RESUMO}

Fêmeas ingurgitadas e parcialmente ingurgitadas de $B$. microplus foram expostas a $600,3000,6000$ e 30000 juvenis infectivos de Steinernema carpocapsae Weiser, 1955 linhagens Santa Rosa e ALL por placa, sob condições de laboratório. Foram investigados para fêmeas ingurgitadas: peso da massa de ovos, período pré-postura, período de postura, tempo de sobrevivência, índice de eficiência reprodutiva, percentual de aclosão de larvas e concentrações letais 50\% e 90\% (CL50 e CL90). Para fêmeas parcialmente ingurgitadas somente foram observados peso da massa de ovos, tempo de sobrevivência, CL50 e CL90. Todos os parâmetros biológicos de fêmeas ingurgitadas foram e parcialmente ingurgitadas foram alterados pela exposição a juvenis infectivos de $S$. carpocapsae linhagens Santa Rosa e ALL $(\mathrm{P}<0,05)$. O aumento das resposta foi diretamente proporcional ao aumento das concentrações de juvenis infectivos por placa $(\mathrm{P}<0,05)$. Os resultados sugerem que nematóides entomopatogênicos podem ter papel primissor no controle de carrapatos dos bovinos.

\section{REFERENCES}

Bennett, G. F. (1974), Oviposition of Boophilus microplus (Canestrini, 1887) (Acarina: Ixodidae). I. Influence of tick size on egg production. Acarologia, 16 : (1), 52-61.

Downes, M. J. and Griffin, C. T. (1996), Dispersal behaviour and transmission strategies of the entomopathogenic nematodes Heterorhabditis and Steinernema. Biocontrol Science and Technology, 6, 347-356.

Fipe, J. P.; Derksen, R. C.; Ozkan, H. E.; Grewal, P. S.; Chalmers, J. J. and Krause, C. R. (2004), Evaluation of a contraction flow field on hydrodynamic damage to entomopathogenic nematodes - A biological pest control agent. Biotechnology and Bioengineering, 86 : (1), 96-107.
Grewal, P. S.; Nardo, E. A. B. and Aguillera, M. M. (2001), Entomopathogenic nematodes: potential for exploration and use in South America. Neotropical Entomology, 30 : (2), 191-205.

Hill, D. E. (1998), Entomopathogenic nematodes as control agents of developmental stages of the Blacklegged tick, Ixodes scapularis. Journal of Parasitology, 84 : (6), 1124-1127.

Kaaya, G. P.; Samish, M. and Glazer, I. (2000), Laboratory evaluation of pathogenicity of entomogenous nematodes to african ticks species. Annals of the New York Academy of Sciences, 916, 303-308.

Kaya, H. K. and Stock, P. (1997), Techniques in insect nematology. In-Manual of techniques in insect pathology, ed. L. A. Lacey. Biological techniques. Academic Press. pp. 281-324.

Kocan, K. M.; Blouin, E. E.; Pidherney, M. S.; Claypool, P. L.; Samish, M. and Glazer, I. (1998a), Entomopathogenic nematodes as a potential biological control method for ticks. Annals New York Academy of Sciences, 355-364.

Lewis, E. E.; Ricci, M. and Gaugler, R. (1996), Host recognition behavior reflects host suitability for the entomopathogenic nematode, Steinernema carpocapsae. Parasitology, 113, 573-579.

Lindegren, J. E.; Valero, K. A. and Mackey, B. E. (1993), Simple in vivo production and storage methods for Steinernema carpocapsae infective juvenile. Journal of Nematology, 25 : (2), 193-197.

Mauléon, H.; Barré, N. and Panoma, S. (1993), Pathogenicity of 17 isolates of entomophagous nematodes (Steinernematidae and Heterorhabditidae) for the ticks Amblyomma variegatum (Fabricius), Boophilus microplus (Canestrini) and Boophilus annulatus (Say). Experimental and Applied Acarology, 17, 831-838.

Piggott, S. J.; Clayton, R.; Matthews, G. A.; Wright, D. J. (2003), Development of a new application apparatus for entomopathogenic nematodes. Pest Managemet Science, 59 : (12), 1344-1348.

Samish, M. (2000), Biocontrol of ticks. Ann. New York Acad. Sci., 916, 172-178.

Samish, M and Glazer, I. (1992). Infectivity of entomopathogenic nematodes (Steinernematidae and Heterorhabditidae) to female ticks of Boophilus annulatus (Arachnida: Ixodidae). Journal of Medical Entomology, 29 : (4), 614-618.

Samish, M.; Alekseev, E. and Glazer, I. (1999a), Interaction between ticks (Acari: Ixodidae) and pathogenic nematodes (Nematoda): susceptibility of tick species at various developmental stages. Journal of Medical Entomology, 36 : (6), 733-740.

Samish, M.; Alekseev, E. and Glazer, I. (1999b), Efficacy of entomopathogenic nematode strains against engorged Boophilus annulatus females (Acari: Ixodidae) under simulated field conditions. Journal of Medical Entomology, 36 : (6), 727-732. 
Samish, M.; Alekseev, E. and Glazer, I. (2000), Mortality rate of adult ticks due to infection by entomopathogenic nematodes. Journal of Parasitology, 86 : (4), 679-684.

Santos, A. P. dos and Furlong, J. (2002), Competição intraespecífica em Boophilus microplus. Ciência Rural, 32 : (6), p. 1033-1038.

SAS Institute, Inc. (1989), SAS/STAT ${ }^{\circledR}$ user's guide. Version 6.11. $4^{\text {th }}$ ed. North Carolina: SAS Institute, Inc., Carey.

Setlar, D. J. (1999) Application methods in different croping systems. In: Proccedings of the workshop on optimal use of inseticidal nematodes in pest management. New Jersey: Polararapu. pp. 31-36.

Veríssimo, C. J. (1993), Prejuízos causados pelo carrapato Boophilus microplus. Zootecnia, 31 : (3/4), 97-106.

Wouts, W. M. (1991), Steinernema (Neoaplectana) and Heterorhabditis species. In: Nickle, W. R. (Ed.). Manual of agricultural nematology. New York. pp. 855-897.

Zhioua, E.; Lebrun, R. A.; Ginsberg, H. S. and Aeschlimann, A. (1995), Pathogenicity of Steirnenema carpocapsae and S. glaseri (Nematoda: Steinernematidae) to Ixodes scapularis (Acari: Ixodidae). Journal of Medical Entomology, 32 : (6), 900-905. 